\title{
PSYCHIATRIC OR DEMONIC DISORDER?
}

\author{
Iwan Firman Widiyanto \\ Sekolah Tinggi Theologia Abdiel \\ praxisboy80@gmail.com
}

\begin{abstract}
Abstrak
Tulisan ini mendalami persoalan mengenai apakah gangguan roh jahat. Khususnya peristiwa kerasukan merupakan hal yang sama dengan gangguan kejiwaan ataukah sesuatu hal yang berbeda. Untuk menjawab pertanyaan itu maka penulis mencoba menguraikan terlebih dahulu perspektif psikologis dalam memandang kerasukan. Selanjutnya juga penulis mendalami perspektif Alkitab, tradisi gereja dan pengalaman di lapangan terkait dengan peristiwa kerasukan. Unsur-unsur tersebut didialogkan satu dengan yang lain dan menghasilkan sebuah kesimpulan bahwa gangguan roh jahat khususnya kerasukan roh jahat adalah sesuatu yang berbeda dengan ganguan kejiwaan meskipun mempunyai gejala yang mirip dan kadang-kadang keduanya saling berkaitan. Sehingga baik gangguan roh jahat maupun gangguan kejiwaan membutuhkan penanganan yang berbeda pula sesuai dengan kasusnya.
\end{abstract}

Keywords: Demonic Disorder, Evil Spirits, Psychiatric Disorder, Possession, Psychology, trance

\section{Introduction}

Incidents of possession are still common in Indonesia. Of course, it attracts people's attention and raises prolonged questions and debates. In general, Indonesians will invite special spiritual leaders to heal the possessed people. People sometimes invite an ustad, a priest or a shaman, then they perform religious rituals to release the victims from evil influences. This way is done with the understanding that the possession occurs because the evil spirit interferes and enters the body of the victim. The spirit controls the body of the victim for his benefit.

On the other hand, psychologists can not handle these possessed cases in a spiritual way forpsychology does not speak and never knowsthe spirit. Psychology scientifically sees the disruptive possession based on the behavior expressed by the victim. ${ }^{1}$ The psychologists ussualy call the victims to be possessed because of psychiatric disorders such as hysteria, bipolar, multiple personality disorder or schyzofrenia.

${ }^{1}$ Siswanto, Psikologi Kesehatan Mental: Awas Kesurupan, (Yogyakarta: Penerbit Andi, 2015), viii. 
The author wants to answer the question of whether psychiatric and demonic disorders have the same understanding that psychologists understand or whether they are actually different matters that require different approach in handling each case. The author will answer the question in a way, first, by explaining the psychological view of demon possession and the ways it is handled. Second, the author will describe biblical or Christian spiritual view of the possession and the ways it is dealt with. Third, the author will describe some of the author's experiences in the face of several cases of direct possession with achristian spiritual approach. Fourth, the author will discuss his experience to answer the problem question. Fifth, the author will summarize the results of the deepening of the discussion to answer the problem question.

\section{Discussion: Psychological View}

Psychology is the science of behavior. So it limits its self to the explanations of the possessed individual's behavior. This science sees the dynamics and how to overcome them scientifically. ${ }^{2}$ This section will describe the psychological view of possession through several scientific perspectives.

First, possession or trance is understood by using a psychoanalysis approach. The psychoanalysis approach was developed by a psychologist named Sigmund Freud (18561939). He found that the structure of the human personality consists of id, ego and superego. Id is in the realm of human consciousness, while ego and superego are in the human unconscious.

In healthy individuals these three personality structures can work integrally. Ego serves as a controller Id and Superego. Id works based on the principle of pleasure and Thanatos (instinct/ dead energy). Ids appears in the form of instincts to gain satisfaction such as eating, sex and other pleasures. While the superego works on the encouragement of values taught without criticizing whether the behavior is in accordance with reality or not. So if the individual fails to encourage the superego, then within him will appear guilt, selfabuse behavior and depression. ${ }^{3}$

A healthy person allows the ego to manage id and superego in a harmonious and balanced way. The ego is able to withstand the impulses of the id who have unlimited wishes by using the good ideal principles possessed by the superego. So the individual can

\footnotetext{
${ }^{2}$ Ibid., 39.

${ }^{3}$ Ibid., 43.
} 
control the unlimited desire. He knows the limit to ending the infinite desire, adjusting to reality.

An unhealthy person happens because his ego is weak. The ego is finally played by the id or superego. When his ego is weak and his id is strong then it produces the attitude of emphasizing on pleasure like sex addicted, greedy, corrupt, irregular life, the desire to get something instantaneously and impulsive. If the id strong and superego die it will make a psychopath/sociopath/ antisocial. Such a person is difficult to have a friend because he has a behaviour of using or sacrificing others for his sake, not having the guilt of always seeing himself righteous and the other guilty. ${ }^{4}$

While the ego is dominated by the superego will lead to such behavior is very rigid in maintaining the norms are believed, thinking black and white and difficult to accept the gray reality, aggressive action when feeling strong or powerful, or guilt can end in selfinjury or suicide. Neurotic disorders such as anxiety, depression, psychosomatic are characteristic of weak individual ego but have strong superego to defeat id. ${ }^{5}$

On the other hand, if the superego and id are equally strong, it will produce a hypocrite. His behavior looks pious, but when he gets the chance, he will use it for his own sake. For example, he will hate other people who do pornography; but on the other hand, he also keeps pornographic videos in his home. That person could be called having a split personality disorder. ${ }^{6}$

By using this theory, possesion occurs because the ego is weak and the id is strong. This is evidenced by seeing the victim possessed mostly experienced by people who are still young, especially women who in fact her ego has not been formed perfectly. ${ }^{7}$

By understanding this analysis then arisecritical thinking that should all young people, especially women will experience the event of possession. Because at that age their ego is still weak. But why do possession occurs in certain people only? Which amount is very small? Not all young women who have weak ego will be possessed. In addition, the author has faced a case of possession often experienced by a grandmother aged eighty years and above. ${ }^{8}$

In his book entitled Psikologi Kesehatan Mental, Siswanto states that possession often occurs over women because of strong patriarchal cultural factors. Women are placed

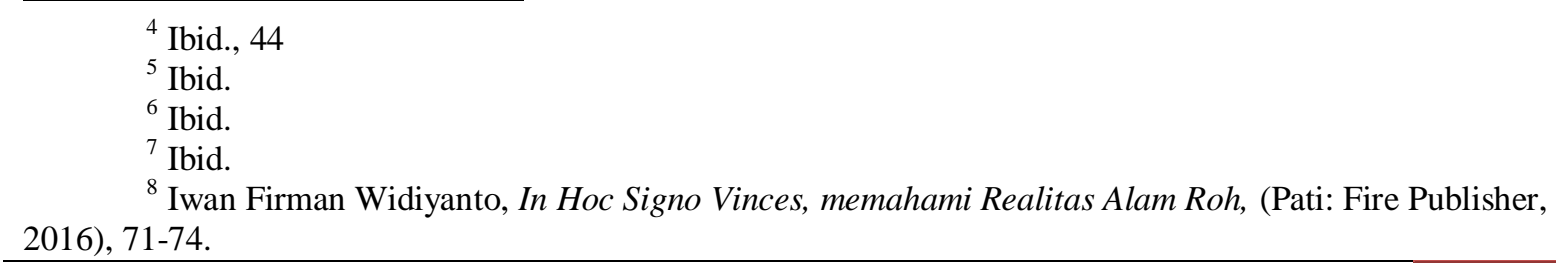

${ }^{8}$ Iwan Firman Widiyanto, In Hoc Signo Vinces, memahami Realitas Alam Roh, (Pati: Fire Publisher, 2016), 71-74. 
under men. Thus the education built weakens the ego and strengthens the female superego. As a result the ego is prone to indulge the id's desire, on the other hand the superego suppresses with guilt. The attraction between the id and the superego in the subconscious causes the ego to divide into a sub ego. In a possessed individu the separation is temporary. While in a permanent separation, until the ego and sub ego are not interconnected, multiple personality disorder occurs.

If this theory is true then it should be all women or at least the majority of women in Indonesia will experience trance, because patriarchal culture is very strong and common in Indonesia, where the role of men placed as superior and women are under it. However, in reality, the number of female victims is not much, the number is small compared to the total number of women in Indonesia.

Siswanto also analyzes that the physical weakness of being sick or tired will make the ego immature or weak. Then it will unable to keep the energy in the subconscious. So, by waiting for a supportive situation then the ego's defenses will be broken. By the time the ego's defense breaks, it becomes confused. Unusual places, which are considered haunted, and the sounds of a possessed crowds, can trigger the breakup of the ego's defenses. ${ }^{9}$

The Critic to this analysis is that it should be in the hospital there will be a lot of trance, because there are many people sick and tired. Hospitals are also regarded as new and alien places, often there are many haunted stories, the atmosphere is gripping, also often heard moans of the sick, but trance is very rare in hospitals compared to the overall ratio of hospital residents.

Perhaps this criticism will be denied by saying that the hospital has been handled by nurses, has been given sedatives and so on, but the psychological prerequisites that trigger trance still felt strongly. In the case of drugs, even tranquilizers, trance can not be prevented from continuing. This is as it happens in the true story of a young German woman named Anneliese Michel, born 21 September 1952, who suffered to death. The story is made in a movie called The Exorcism of Emily Rose. It was narrated in the film that Anneliese had been taken to a psychiatrist and had been given a sedative, but possession still existed on her. She has also been prayed by the pastor with the exorcist's prayer.

In the film it is told that Anneliese has suffered from demon possession to death as an option to do God's will. It was revealed from the diary she wrote. In a spiritual

\footnotetext{
${ }^{9}$ Ibid., 47.
} 
experience, God offers two things to Annaliese. First, healed or free from Satan's attack, but no impact on the world. Or second, she still suffered to death but the event will bring a big impact or change in society. Then Anneliese chose the second one. So after her death, it was witnessed that the number of church congregatios in the United State increased sharply. It wa as if Annaliese was about to remind the evil spirit that it was not a myth or a fairy tale even though modern times with secularism and rationalism grew longer.

Siswanto also criticized religious education that only emphasizes id and strengthens the superego, so the ego becomes weak. The education will produce individuals who are neurotic and split personality/ hypocrital. ${ }^{10}$ Siswanto's statement is of course willing to say that religious education became one of the supporting factors possessed. If this statement is true then more people will have to be possessed. But in an area consisting of several churches there may be no cases of possession. The theory which according to Siswanto seems logical but actually not in accordance with reality.

By understanding Freud's theory, Siswanto said that the mechanism of drowning the ego into the subconscious process is not realized by the person. People who experience it will not remember it. A person who experiences possession, consciousness will reappear when the ego feels secure. If the ego is still feeling threatened it will be difficult to return to consciousness. Whereas in reality, in the case of possessed person like Ika and Ela, they are fully conscious. They know what is going on inside them, and are able to remember it well. In fact both experience a beautiful feeling, calm and peace when realizing theirsoulis brought closer to heaven. They also get a certain vision which they then remember until they regain consciousness. Of course this reality is very contrary to Siswanto's opinion that the possessed person will not be aware of what he is doing. Although there is a kind of possession that actually causes unconsciousness, but at least from the two samples I interviewed, both showed their consciousness when experiencing demon possession.

Besides, the possessed person does not always experience tremendous anxiety. In the process when his spirit is brought to something beautiful and lonelyas heaven, he also experiences a beautiful and calm atmosphere, even experiencing an unspeakable bliss. ${ }^{11}$

Second, trance is approached with the theory of Behaviorism. This theory says that trance is the result of learning to play drama to get attention. Starting from childhood, when asking for something then he tries to get it by doing such an emotional acts like by screaming and getting angry. By doing so, the environment will then pay attention and

\footnotetext{
${ }^{10}$ Ibid., 45.

${ }^{11}$ Widiyanto, In Hoc Signo Vinces, 106-109.
} 
grant his request. According to this theory of behaviorism, possession occurs when a person is already shrewed in playing the drama to get his wish. Because of so ingenious and also because of the development of a more perfect brain, the person is able to play the drama as if real. So initially this theory wants to declare that possession is the result of high-level drama to get attention to the achievement of a desire. ${ }^{12}$

This behaviorism theory may be able to explain certain mental disorders but is not appropriate if applied to cases of possession. In the experience of confronting a trance victim, I hardly ever encounter a trance victim who asks for something for his own personal interest. Most demands of the possessed person are the demands of the spirit that pervades the victim. For example, a possessed woman speaks on behalf of another person asking for the blood of the person or the blood of a chicken; ${ }^{13}$ there is also a prayer for peace $;{ }^{14}$ or who publicly declaresthe purpose of borrowing the victim's body is that he can see the world with a real physical body. ${ }^{15}$ Of course, if possessed is a game to fulfill personal desires then the form of demand will lead directly to a particular wish or desire of the victim.

Third, the trance approach to humanistic theory. This theory states that trance occurs because the environment where the victim lives is an unhealthy environment. Environmental situations are considered as threatening the victim, making him feel uncomfortable. If such a situation continuous, then the energy produced, which should develop, is ultimately used to defend itself. If this situation persists, it will cause psychological union to be disrupted until it breaks. As a result individuals experience various disorders such as anxiety, depression from mild to severe levels (Skisophrenia). Potentially possessed individuals usually live in poor, unhappy, persistent, annoyed and overextended situation or loss of the nearest person. ${ }^{16}$

Again this theory may apply to mental disorders, but not to trance cases; otherwise the poor community in the suburbs will tend to experience trance. The Annelise story filmed in The Exorcism Of Emily Rose shows that Annaliese was originally a happy girl for being in a warm and caring family environment. She is from a faithful and economically well-off Catholic family. The Annaliese case shows that Trance is a unique case that is not always triggered by an unhealthy environment.

\footnotetext{
${ }^{12}$ Siswanto, Psikologi Kesehatan Mental, 54.

${ }^{13}$ Widiyanto, In Hoc Signo Vinces, 86-87.

${ }^{14}$ Ibid., 48.

15 Ibid., 82-83.

${ }^{16}$ Siswanto, Psikologi Kesehatan Mental, 57-58.
} 
Fourth, by using biopsychological approach. Biopsychology is the knowledge of the biological basis of behavior. This view examines the bodily reactions of possessed subjects. Usually, the trance starts with a chronic fear, anger and discomfort (continuous for a long time). These feelings trigger the body's self-defense mechanism against danger by tightening muscles and shortness of breath. Furthermore, the intake of oxygen to the brain becomes reduced. This makes the brain unable to perform its main function that think clearly. As the brain experiences this chaos, subjects experience hallucinations and other perceptual disorders. All the unpleasant experiences and what have been thought and stored in the brain runs uncontrollably. ${ }^{17}$ According to biopsychology that is then called trance.

The theory seems logical but in fact it is not appropriate when applied to cases of possession. Some cases of trance that I handle do not show shortbreaths. At first it seemed not angry or hysterical, but rather calm, silent and his eyes were blank. Although there are also cases of possessed people who screamed angry. In the case of Ika, the spirit that enters her can show the expression of a normal person. ${ }^{18}$ Thus, the insensitive person considers Ika free from evil spirits. Actually spirit is still master. Only when the songs of praise are raised, the spirit s can not continue to pretend. He will then show certain manifestations ${ }^{19}$. In the case of Ika, even the spirit that will come out from her calmly greets everyone present, one by one audience's hands were kissed. After that the spirit left the victim's body. ${ }^{20}$ When the spirit leaves the body of the victim, the victim usually immediately lying limp, fainted for a moment, then immediately awaken.

\section{Biblical View}

Christianity and other religions believe that trance occurs because there is another spirit that pervades one's body and controls it. The scriptures record teachings or stories relating to spirits, especially the spirits of the dead. The Old Testament implies that the spirits of the dead can still relate to humans. The nations around Israel have a habit of asking for help or guidance of life from the spirits of the dead. ${ }^{21}$ But God forbids people to follow the way that the nations do. God wants people to rely on God only. God wants his people to keep holy lives by abstaining from the spirits of the dead.

\footnotetext{
${ }^{17}$ Ibid., 59-60.

${ }^{18}$ Widiyanto, In Hoc Signo Vinces, 82.

${ }^{19}$ Ibid., 82.

${ }^{20}$ Ibid., 83.

21 Ibid., 49.
} 
"Do not defile yourselves by turning to mediums or to those who consult the spirits of the dead. I am the LORD your God (Leviticus 19:31).",22

God is very firm against the people who are associated with the spirits of the dead. He will punish the people who ask for help or guidance to the spirits of the dead. He will also punish the person who becomes the medium of the spirit of the dead with the people.

"Men and women among you who act as mediums or who consult the spirits of the dead must be put to death by stoning. They are guilty of a capital offense (Leviticus 20:27)."23

9 "When you enter the land which the LORD your God gives you, you shall not learn to imitate the detestable things of those nations. 10 "There shall not be found among you anyone who makes his son or his daughter pass through the fire, one who uses divination, one who practices witchcraft, or one who interprets omens, or a sorcerer, $\underline{\mathbf{1 1}}$ or one who casts a spell, or a medium, or a spiritist, or one who calls up the dead. 12 "For whoever does these things is detestable to the LORD; and because of these detestable things the LORD your God will drive them out before you. $\underline{\mathbf{1 3}}$ "You shall be blameless before the LORD your God. 14 "For those nations, which you shall dispossess, listen to those who practice witchcraft and to diviners, but as for you, the LORD your God has not allowed you to do so (Deuteronomy 18:8-14),"24

This passage of the scriptures state that the spirits of the dead can even be invited back by man but God hates the practice. The Bible also records the story of King Saul who asked for clues from the spirit of Samuel when he felt frustrated by being squeezed by the troops of the Philistine. With the help of a shaman, the spirits came out to Saul. But the spirit of Samuel declared that he was troubled because he had to face Saul. Then Samuel's spirit spoke with God to fight Saul. He annouced a prophecy about Saul and his family's death. This story can be seen at 1 Samuel 28: 3-20. Later the prophecy of Samuel's spirit is fulfilled; "So Saul and his three sons died, and all his house died together (1 Chronicle 10:6). ${ }^{, 25}$

The Bible also notes that Saul's actions invited the spirit of Samuel to be hated by God. It is said that Saul had been unfaithful to God for asking for help from the spirits of the dead.

"13 So Saul died for his trespass which he committed against the LORD, because of the word of the LORD which he did not keep; and also because he asked counsel of a medium, making inquiry of $i t, \underline{\mathbf{1 4}}$ and did not inquire of the LORD. Therefore He killed him and turned the kingdom to David the son of Jesse (1 Chronicles 10:13-14).,26

\footnotetext{
${ }^{22} \mathrm{http}: / /$ biblehub.com/leviticus/19-31.htm, (diakses tanggal 7 November 2017)

${ }^{23}$ Ibid.

${ }^{24} \mathrm{http}: / /$ biblehub.com/context/deuteronomy/18-9.htm, (diakses tanggal 7 November 2017)

${ }^{25} \mathrm{Ibid}$.

${ }^{26} \mathrm{http} / / /$ biblehub.com/context/1_chronicles/10-13.htm, (diakses tanggal 7 November 2017)
} 
The prophet Isaiah also forbade the Ummah from seeking guidance from the spirits. He reminded the people to ask God for help only.

"19 Someone may say to you, "Let's ask the mediums and those who consult the spirits of the dead. With their whisperings and mutterings, they will tell us what to do." But shouldn't people ask God for guidance? Should the living seek guidance from the dead? (Isaiah 8:19)",27

On the other hand, Proverbs writes a belief that there is a special place to gather the spirits.

"16 The man who strays from the way of wisdom will come to rest in the assembly of the departed spirits (Proverb 21:16)."28

But only by the power of God, the will or permission of God alone, the soul of a dead person can return to touch with living people.

“ㄸ The LORD brings death and gives life; He sends some to Sheol, and He raises others up (1 Samuel 2:6).,29

But the general provisions remain in force, as Job states, that the dead will not reappear.

"9 As a cloud fades away and vanishes, so the one who goes down to Sheol will never rise again (Job 7:9)."30

Thus, the spirits that manifest themselves to humans or possess human beings, all with the permission and will of God alone. So even though a spirit caller invites the spirit of the dead to come, but if God does not allow it, it will not happen. ${ }^{31}$ Because God rules over the world of the dead, as Proverbs affirmed:

"11 Sheol and Abaddon lie open before the LORD - how much more, human hearts (Proverb 15:11)., 32

The scriptures imply that there is a special place for the spirit of the deceased. The first place is often referred to as sheol or the world of the dead. This place is often depicted below. It is a resting place for the waiting spirits of God. An unfaithful or possibly

\footnotetext{
${ }^{27}$ http://biblehub.com/nlt/isaiah/8.htm, (Diakses tanggal 5 Desember 2017).

${ }^{28}$ Ibid.

${ }^{29} \mathrm{http} / / /$ biblehub.com/hcsb/1_samuel/2.htm, (Diakses tanggal 5 Desember 2017).

${ }^{30} \mathrm{http} / / /$ biblehub.com/hcsb/job/7.htm, (Diakses tanggal 5 Desember 2017).

${ }^{31}$ Widiyanto, In Hoc Signo Vinces, 56.

${ }^{32} \mathrm{http} / / /$ biblehub.com/hcsb/proverbs/15.htm, (diakses tanggal 5 Desember 2017).
} 
lukewarm people is placed in this place after his death. Other places point to the sky, place on the ground. A better place can be called the Kingdom of Heaven, a place reserved for believers and faithful to do God's commands. ${ }^{33}$

" 2 If they dig down to sheol, from there My hand will take them; if they climb up to heaven, from there I will bring them down (Amos 9:2)."34

"15 And you, Capernaum, will you be exalted to heaven? No, you will go down to Hades! (Likas 10:15)",35

Luke records Jesus' perspective that the person who repents and is truly loved by God when he dies he will be taken to heaven. Paul also declared his vision to the Corinthians, that there was a man who was raised directly by God to heaven.

" $\underline{43}$ And He said to him, "I assure you: Today you will be with Me in paradise (Luke 23:43)."36

"1 Boasting is necessary. It is not profitable, but I will move on to visions and revelations of the Lord. 2 I know a man in Christ who was caught up into the third heaven 14 years ago. Whether he was in the body or out of the body, I don't know, God knows. 3 I know that this man-whether in the body or out of the body I don't know, God knows - 4 was caught up into paradise. He heard inexpressible words, which a man is not allowed to speak (2 Corinthian 12:14)."37

The New Testament also tells of Jesus's encounter with Elijah and Moses on the mountain before His disciples. However, at that time Elijah and Moses did not live in the world anymore. Elijah had been taken to heaven directly by the fire train while Moses was dead for a long time.

"1 After six days Jesus took Peter, James, and his brother John and led them up on a high mountain by themselves. 2 He was transformed in front of them, and His face shone like the sun. Even His clothes became as white as the light. 3 Suddenly Moses and Elijah appeared to them, talking with Him. 4 Then Peter said to Jesus, "Lord, it's good for us to be here! If You want, I will make three tabernacles here: one for You, one for Moses, and one for Elijah."5 While he was still speaking, suddenly a bright cloud covered them, and a voice from the cloud said: This is My beloved Son. I take delight in Him. Listen to Him! 6 When the disciples heard it, they fell facedown and were terrified. 7 Then Jesus came up, touched them, and said, "Get up; don't be afraid." 8 When they looked up they saw no one except Him-Jesus alone. 9 As they were coming

\footnotetext{
${ }^{33}$ Widiyanto, In Hoc Signo Vinces, 57.

${ }^{34} \mathrm{http} / / /$ biblehub.com/hcsb/amos/9.htm, (diakses tanggal 5 Desember 2017).

${ }^{35} \mathrm{http}: / /$ biblehub.com/hcsb/luke/10.htm, (diakses tanggal 5 Desember 2017).

${ }^{36} \mathrm{http} / / /$ biblehub.com/hcsb/luke/23.htm, (diakses tanggal 5 Desember 2017).

${ }^{37} \mathrm{http} / / /$ biblehub.com/hcsb/2_corinthians/12.htm, (diakses tanggal 5 Desember 2017).
} 
down from the mountain, Jesus commanded them, "Don't tell anyone about the vision until the Son of Man is raised from the dead (Matthew 17:19).",38

This biblical study summarizes the following: First, those who love God, those who live in repentance, believe and are faithful to God, when they die, they will be brought directly into the kingdom of Heaven. Second, the one who rebels against God, who does not want to live in repentance, then his death will soon be placed in tremendous suffering. Third,a person whose attitude is vague or lukewarm in the presence of God, when he dies, he will be placed on the cessation of spirits. Fourth, whether a person is in heaven, in hell or at the halt of the spirit, by God's will or permission, he or she may appear or communicate with the living. ${ }^{39}$ This research shows that the Bible as the basis of the Christian view believes in the spirit of the dead. Even spirits can roam the earth, even under God's control.

\section{Church Tradition}

Church tradition also believes in the existence of evil spirits or often so-called demons. But the existence of the evil spirit is indeed accepted by faith or dogma that is taught. In the tradition of the Catholic church, especially through the Council of Lateran IV states that Satan (1) is essentially a spirit ... (2) is created by God, (3) is good, (4) but falls into $\sin (5)$ because of their own free will and that they (6) are punished forever. The new Catechism also repeats it (391-395). ${ }^{40}$ The Church holds the belief in the existence of evil spirits. Peter Kreeft states that the church's belief in the existence of evil spirits does not necessarily push the church back two hundred years. The Church simply follows what God teaches. $^{41}$

Peter Kreeft tries to answer the question often asked by secularists. The questions are as follows: "Is'n it psychologically unhealthy to believe that the devil exists? Is'n that a setback, a fear of believing in superstition and witch hunts like those of the Middle Ages?"

So Peter responded with an illustration that if there were a beast then would it be unhealthy if someone believed that the animal existed? would not it be more unhealthy to

\footnotetext{
${ }^{38} \mathrm{http}: / /$ biblehub.com/hcsb/matthew/17.htm, (diakses tanggal 5 Desember 2017)

${ }^{39}$ Widiyanto, In Hoc Signo Vinces, 61.

${ }^{40}$ Peter Kreeft, Angels \& Demons, Malaikat Dan Iblis, Apa Yang Kita Tahu Tentang Mereka? (Malang: Dioma, 2006), 125-126.

${ }^{41}$ Ibid., 126.
} 
pretend that the beast did not exist? Peter refuses people to say whether or not something is merely by observing the psychological effects experienced by those who believe in it. ${ }^{42}$

Peter also explained that belief in the existence of evil spirits or demons is part of divine revelation. So, if people believe in scripture but reject the existence of evil spirits or demons, it means to place themselves as judges of the divine revelation. ${ }^{43}$

In this case the demons and the spirits of the dead are two different entities despite being spiritual. Both demons and the spirits of the dead have the ability to penetrate the human body, allthough such incidents are rare.

\section{Experience fromThe Field}

There are many personal experiences in fields related to the existence of the spirits of the dead. A psychiatrist named G.G. Ritchie wrote down his experience when he died and then lived again. He told that his spirit went out of his body. He could see the bod, then he felt a mild sensation, his spirit could penetrate the wall and able to drive at high speed. Then at its climax he met also with the luminous creatures that gave him peace. ${ }^{44}$

Ritchie experiment is similar to the results of research conducted by Raymond A. Moody JR. He is a psychiatrist who teaches philosophy of medicine, ethics and logic. He has researched over a hundred people in America who have undergone clinical deaths but then returned to life. Apparently the results of his research reinforced by Elisabeth KublerRoss's reasearch, a psychiatrist, about the same thing, though these two people did not know each other before.

Some important points related to the second research are as follows: a dead person usually does not realize that he is dead. He is just confused to see and hear the people who are still living around him. He can also see his dead body. There was a feeling of wanting to return to his body. In his confusion there are usually other spirits who are close to him, meeting him with the intention of accompanying in a transitional period between the real world and the spirit world. Their hearing power, vision power and movement skills are increasing. In the end they will meet the luminous creatures that give peace. Usually after meeting the creature, they do not want to return to the world. ${ }^{45}$

\footnotetext{
42 Ibid.

${ }^{43}$ Ibid. 127

${ }^{44}$ G.G.Ritchie, Aku Pernah Mati, (Jakarta : BPK Gunung Mulia, 1983), 42-58.

${ }^{45}$ Raymond A. Moody JR, Hidup Sesudah Mati, (Jakarta: Gramedia, 1979), 32-85.
} 
The results of interviews with demon-possessed indicate a spirit world. They feel that their spirit is pulled out of the body. They can see the existence of the body, then be somewhere. In the story of Ika, who is possessed by an evil spirit, she was taken up to the gates of heaven. ${ }^{46}$

\section{Conclusion}

The testimony of the scriptures, church traditions and field experiences show that the evil spirit is real. The spirit is very likely to possess and control a person, although such incidentsare very rare. Such phenomena are then referred to as a devil's disorder. But psychiatric disorders occur because of traumatic events that led to the breakdown of personality. Psychiatric disorders are further triggered by an uncomfortable or oppressive environment.

Persons possessed by evil spirits, harassed by demons, do have similar manifestations as those who suffer from psychiatric disorders. However, the psychiatric and demonic disorder are two different things. The manifestation of psychiatric disorder that occurs is the cry of anger, while the devil's disorder does not always manifest in anger. A person who suffers from a psichiatric disorder usually does not remember what is going on. Someone who is bullied by the devil often realizes what is going on, but can not do anything about it.

Therefore, the handling of psychiatric and demonic disorder are also different. Psichiatric disorders usually require a long process of therapy. In case of multiple personality even the patient can not be cured. However, a demonic disorder when handelled with proper spiritual approach can then be driven away immediately at that moment. The spiritual approach is usually to pray, fast, free all vengeance, life in repentance and forgiveness. While the approach to psychiatric disorders, especially hysteria or trance, is done by silencing the victim to calm down. The victim will be aware of itself, and then carried out the process of counseling and therapy.

\section{Bibliography}

Angels, Peter Kreeft \& Demons. Malaikat Dan Iblis, Apa Yang Kita Tahu Tentang Mereka?. Malang: Dioma, 2006.

Moody JR, Raymond A. Hidup Sesudah Mati. Jakarta: Gramedia, 1979.

${ }^{46}$ Widiyanto, In Hoc Signo Vinces, 191-192. 
Ritchie, G.G. Aku Pernah Mati. Jakarta: BPK Gunung Mulia, 1983.

Siswanto. Psikologi Kesehatan Mental: Awas Kesurupan. Yogyakarta: Penerbit Andi, 2015.

Widiyanto, Iwan Firman. In Hoc Signo Vinces, memahami Realitas Alam Roh. Pati: Fire Publisher, 2016. 